\title{
OUTCOMES AND EFFECTIVENESS OF PERCUTANEOUS INTERVENTION IN PATIENTS WITH TAKAYASU'S ARTERITIS
}

\author{
Mustafa Yildiz' , Ahmet Cagri Aykan², Suleyman Karakoyun ${ }^{3}$, Banu Sahin Yildiz ${ }^{4}$, Nazire Aladag Baskurt ${ }^{4}$, Alparslan Sahin ${ }^{5}$, Tayyar Gokdeniz ${ }^{2}$, \\ Hakan Hasdemir ${ }^{6}$, Mehmet Soy
}

\begin{abstract}
Aim. Takayasu's arteritis (TA) is a chronic inflammatory disease that affects predominantly the aorta. Percutaneous intervention (PI) may be use the TA. In this manuscript, we studied the outcomes (in-hospital and 6 months later) and effectiveness of PI in patients with TA.

Material and methods. The study was performed on 24 consecutive patients (39.3 \pm 11.8 (20-61) years; 4 men and 20 women) with TA who were treated with PI, surgical or medical therapy. Nine patients ( 7 females, 2 male) underwent PI. PI was performed after the erythrocyte sedimentation rate had been normalized in patients with TA.

Results. Although 9 patients received PI with stent for subclavian, carotid, renal and coronary artery, 1 patient received PI with only balloon for brachial artery. One percutaneous transluminal angioplasty and 10 stentings were performed. There was not any complication during interventional procedure. The patients were followed for 6 months. After 6 month, the arteries treated were patent and showed no proliferative lesions in Doppler ultrasound at 8 patients. At a woman patient, left subclavian artery restenosis was determined in Doppler ultrasound and confirmed by angiography. During angiography the stenotic lesion has been successfully treated with balloon angioplasty.

Conclusions. Takayasu's patients with active systemic disease must receive immunosuppressive therapy before PI. PI was performed after the active period such as during normal erythrocyte sedimentation rate. In these circumstances, $\mathrm{PI}$ in patient with TA may be safely and much less traumatic. Also, recurrence of stenosis in patient with TA has been treated successfully by reintervention without significant complications.
\end{abstract}

Russ J Cardiol 2014, 1 (105), Engl.: 11-14

Key words: Takayasu arteritis, percutaneous intervention, surgery, inflammation.

${ }^{1}$ Department of Cardiology, Kartal Koşuyolu Yuksek Ihtisas Educational and Research Hospital, Istanbul (Formerely institute of author: Sakarya University); ${ }^{2}$ Department of Cardiology, Ahi Evran Chest and Cardiovascular Surgery Educational and Research Hospital, Trabzon; ${ }^{3}$ Department of Cardiology, Kartal Koşuyolu Yuksek Intisas Educational and Research Hospital, Istanbul; ${ }^{4}$ Department of Internal Medicine, Dr Lutfi Kırdar Kartal Educational and Research Hospital, Istanbul; ${ }^{5}$ Department of Cardiology, Dr Sadi Konuk Educational and Research Hospital, Istanbul; ${ }^{6}$ Department of Cardiology, Dr. Siyami Ersek Cardiovascular and Thoracic Surgery Training and Research Hospital, Istanbul; ${ }^{7}$ Department of Rheumatology, Hisar Intercontinental Hospital, Istanbul, Turkey.

Corresponding author. Dr. Mustafa Yildiz, M.D., Ph.D, Prof. Cardiologist, Internal Medicine Specialist and Physiologist, Bayar Cad, Gulbahar Sok, A Blok, D6, Kozyatağı/Istanbul, Tel: +9005323711701, e-mail: mustafayilldiz@yahoo.com

$\mathrm{PI}$ - percutaneous intervention, TA - Takayasu's Arteritis.

Received February 22, 2013.

Revision received March 12, 2013.

Accepted March 19, 2013.

\section{РЕЗУЛЬТАТЫ И ЭФФЕКТИВНОСТЬ ЧРЕСКОЖНОГО ВМЕШАТЕЛЬСТВА У БОЛЬНЫХ С СИНДРОМОМ ТАКАЯСУ}

Mustafa Yildiz, Ahmet Cagri Aykan, Suleyman Karakoyun, Banu Sahin Yildiz, Nazire Aladag Baskurt, Alparslan Sahin, Tayyar Gokdeniz, Hakan Hasdemir, Mehmet Soy

Цель. Синдром Такаясу (СТ) - это хроническое воспалительное заболевание, поражающее преимущественно аорту. Чрескожные вмешательства (ЧВ) возможно использовать при ТП. В этой работе, мы изучили результаты (в стационаре и 6 месяцев позднее) и эффективность ЧВ у пациентов с СТ.

Материал и методы. Исследование проводили на 24 пациентах $(39.3 \pm 11.8$ (20-61) лет; 4 мужчин и 20 женщин) с СТ, которым было проведено ЧВ, хирургическое или медикаментозное лечение. Девять пациентов (7 женщин, 2 мужчин) прошли ЧВ. ЧВ было проведено пациентам с СТ после нормализации Соэ

Результаты. Хотя у 9 пациентов ЧВ проведено путем стентирования подключичной, сонной, почечной и коронарной артерии, 1 пациент получал ЧВ только через баллонную ангиопластику на плечевой артерии. Всего было выполнено одна чрескожная транслюминальная ангиопластика и 10 стентирований. Не было отмечено ни одного осложнения во время интервенционной процедуры. Пациенты наблюдались в течение 6 месяцев после пребывания в стационаре. После 6 месяцев леченные артерии были сохранны и не проявляли

\section{Introduction}

Takayasu's arteritis (TA) is a chronic inflammatory disease that affects the large vessels, predominantly the aorta and its main branches and the pulmonary arteries, and it leads to vessel wall thickening, fibrosis, stenosis, and thrombus formation. The symptoms of this disease reflect the patient's high blood pressure and end organ ischemia including coronary, cerebral, and extremity ischemia. The никаких пролиферативных поражений при допплеровском исследовании у 8 пациентов. У одной пациентки ультразвуковой допплерографией был определен рестеноз левой подключичной артерии, что было подтверждено ангиографией. Во время проведения ангиографии стенозирующее поражение было успешно вылечено с помощью баллонной ангиопластики.

Заключение. Пациенты с СТ и активным системным заболеванием должны получать иммуносупрессивную терапию перед ЧВ. ЧВ было проведено после активного периода, при нормальной СОЭ. При этих условиях ЧВ у пациентов с СТ может быть безопасно и гораздо менее травматично. Кроме того, рецидивы у пациентов с СТ возможно успешно лечить с помощью повторных вмешательств без существенных осложнений.

Российский кардиологический журнал 2014, 1 (105), Англ.: 11-14

Ключевые слова: артериит Такаясу, чрескожное вмешательство, хирургии, воспаление.

mortality rate of TA is between 0 and $30 \%$ at five years, and the cause of death can be with congestive heart failure, coronary artery disease, cerebrovascular disease and renal failure $[1,2]$. Therefore, an appropriate medical and invasive therapy is required for patients suffering from progressive disease. Some studies have revealed excellent results of percutaneous intervention for treating patients with TA [3, 4]. In this manuscript, we studied the outcomes (in hospi- 
tal and six month later) and effectiveness of percutaneous intervention in patients with TA.

\section{Material and methods}

Patient population. From April 2005 to January 2010, a study was performed on 24 consecutive patients [ $39.3 \pm 11.8$ (20-61) years; 4 men and 20 women] with TA who were treated with percutaneous intervention, surgical or medical therapy. Although lesions greater than $40 \%$ were included in this study, lesions greater than $70 \%$ reduction in vessel cross-sectional area of the vessel were treated by percutaneous intervention. Nine patients (7 females, 2 male) underwent percutaneous intervention. The patients had admitted to hospital complaining of headache, weakness and upper extremity claudication, also two patient had Class II angina pectoris. TA was diagnosed according to the American College of Rheumatology Criteria for the Classification of TA [5]. Patients with active systemic disease, as manifested by symptoms such as fever, musculoskeletal pains, or increased erythrocyte sedimentation rate received immunosuppressive therapy including steroids and/or methotrexate, azathioprin and cycloposphamide before percutaneous intervention. The doses of immunosuppressive drugs were adjusted according to each patient's erythrocyte sedimentation rate and clinical status. Percutaneous interventions were performed after the erythrocyte sedimentation rate had been normalized $(<15 \mathrm{~mm} / \mathrm{h})$ in these patients.

Interventional Procedure. Informed and written consent was obtained from all patients before the procedure. All patients were administered loading doses of acetylsalicylic acid $300 \mathrm{mg}$ and clopidogrel $600 \mathrm{mg}$ before percutaneous intervention. On admission anticoagulation was performed with unfractionated heparin $5000 \mathrm{IU}$ iv bolus followed by 24000 IU over 24 hours. During percutaneous intervention $5000-7500 \mathrm{IU}$ iv bolus is given followed by $1000 \mathrm{IU}$ an hour later, then additional heparin to achieve an activated clotting time of 250-350 seconds. After the procedure, acetylsalicylic acid $(100 \mathrm{mg} /$ once daily) was prescribed indefinitely. Clopidogrel was prescribed continuously for 1 year. All procedures were performed with the patients under local anaesthesia with sedatives. The electrocardiogram, arterial oxygen saturation, and blood pressure parameters were closely monitored. Using standard catheterization techniques, a $6 \mathrm{~F}$ to $8 \mathrm{~F}$ guiding catheter was introduced into the proximal portion of the stenotic artery. Patients with a significant stenosis (those with an estimated greater than $70 \%$ reduction in vessel cross-sectional area) of the vessel were treated by angioplasty or stenting. Following angioplasty or stenting, selective angiography was

Affected vessels, treatment options and procedure site

\begin{tabular}{|c|c|c|c|c|}
\hline Age, Sex & Hypertension & Affected vessels & Treatment & Procedure site \\
\hline $50, F$ & + & LSCA & Medical & - \\
\hline $32, \mathrm{M}$ & + & LSCA, LRA, RRA, LVA & Stent & LRA \\
\hline $20, F$ & - & LSCA & Medical & - \\
\hline $38, F$ & - & RSCA & Medical & - \\
\hline $49, \mathrm{~F}$ & + & CABGX3 (LAD, D1, RCA), LSCA, RVA & Stent & LSCA, RCA \\
\hline $55, \mathrm{~F}$ & + & Op LSCA, LCCA, LRA & Stent & LSCA \\
\hline $39, F$ & - & Op LSCA, RCCA & Stent & LSCA \\
\hline $61, \mathrm{~F}$ & - & Op LSCA, RCCA, RVA & Medical & - \\
\hline $43, F$ & - & LSCA, RCCA, LCCA, RAA & Stent & LSCA \\
\hline $32, \mathrm{M}$ & - & CABGX2 (LAD, RCA), RRA, RCCA & Medical & - \\
\hline $49, F$ & - & RAA, RBA, LBA & Medical & - \\
\hline $32, M$ & + & RSCA, RRA, LVA & Stent & RSCA, RRA \\
\hline $26, \mathrm{~F}$ & - & Op LSCA, LCCA & Stent & LCCA \\
\hline $38, F$ & - & RSCA & Op & RSCA \\
\hline $41, \mathrm{~F}$ & - & RSCA, RCCA & Op & RCCA \\
\hline $20, \mathrm{~F}$ & - & RBA, LBA, LSCA & PTA & LBA \\
\hline $35, F$ & - & RSCA, RAA & Medical & - \\
\hline $30, F$ & - & RCCA, LCCA & Medical & - \\
\hline $47, \mathrm{~F}$ & - & RCCA, LCCA, RSCA, RVA & Medical & - \\
\hline $42, F$ & - & LCCA, LSCA, LVA & Medical & - \\
\hline $61, \mathrm{~F}$ & - & RSCA & Medical & - \\
\hline $30, F$ & - & LCCA, LSCA & Medical & - \\
\hline $24, M$ & - & LCCA, RCCA, LSCA, RSCA & Medical & - \\
\hline
\end{tabular}

Abbreviations: LSCA — left subclavian artery, LRA — left renal artery, RRA — right renal artery, LVA — left vertebral artery, RSCA — right subclavian artery, CABG — coronary artery bypass grafting, PTA - percutaneous transluminal angioplasty, LAD - left anterior descending artery, D1 - diagonal artery 1, Cx - circumflex artery, RCA - right coronary artery, RVA - right vertebral artery, Op - operation, CA - celiac artery, RCCA - right common carotid artery, LCCA — left common carotid artery, RAA - right axiller artery, RBA - right brachial artery, LBA - left brachial artery. 
performed to determine the degree of dilation and whether dissection had occurred and to evaluate the intracranial circulation for signs of distal embolization.

Definitions and Follow-up. An intervention was considered technically successful if the residual stenosis was $<30 \%$. Six month later success of the percutaneous intervention was documented by Doppler ultrasound. In this technique, restenosis was defined by the presence of symptom recurrence and $>50 \%$ restenosis.

Statistical analysis. Statistics were obtained using the ready-to-use programme of SPSS version 8.0. All the values such as age, period of the disease, erythrocyte sedimentation rate and stent size were expressed as mean \pm standard deviation.

\section{Results}

The affected vessels, treatment options and percutaneous intervention site are summarized in Table 1. The mean period of the disease was $5.4 \pm 4.1(1-13)$ years. The pre-treatment erythrocyte sedimentation rate was $54.91 \pm 25.10 \mathrm{~mm} / \mathrm{h}$. Percutaneous intervention was performed after the erythrocyte sedimentation rate had been normalized $(9.80 \pm 2.10 \mathrm{~mm} / \mathrm{h})$ in these patients. While five patients had hypertension, none of the patients had diabetes mellitus and hyperlipidemia. Two patients treated before coronary artery bypass surgery and had a left internal mammarian artery (LIMA) bypass graft. While 2 patient undergone surgical revascularization, 12 patients received medical treatment. Although 9 patients received percutaneous intervention with stent, 1 patient received percutaneous intervention with only balloon. One percutaneous transluminal angioplasty $(4 \mathrm{X} 30 \mathrm{~mm})$ and 10 stentings were performed [Mean size: $7.70 \pm 1.82$ (3.0-9.0) mm X 31.00 14.17 (12.0-58.0) mm]. Percutaneous coronary intervention (right coronary artery stenting) and left subclavian artery stenting were performed 1 patient. $3.0 \times 12 \mathrm{~mm}$ bare metal stent was used for proximal lesion of right coronary artery. Left renal artery stenting was performed 1 patient, subclavian artery (3 left, 1 right) stenting was performed 4 patients, and left common carotid artery stenting was performed 1 patient. Stent for right renal artery and right subclavian artery were performed 1 patients. Percutaneous transluminal angioplasty for left brachial artery was performed 1 patient. There were not any complication during interventional procedure. The patients were followed for 6 months. After 6 month, the arteries including subvlavian, brachial, carotid and renal treated were patent and showed no proliferative lesions in Doppler ultrasound at 8 patients. Also, transthoracic echocardiography and treadmill test (for 1 patient) were normal 6 months after the procedure. At a woman patient, left subclavian artery restenosis was determined in Doppler ultrasound and confirmed by angiography. During angiography the stenotic lesion has been successfully treated with balloon angioplasty.

\section{Discussion}

TA can be defined as a chronic inflammatory arteritis that attacks the aorta and its main branches [1, 2]. Management strategies for TA include medical treatment with steroids or immunosuppressive agents such as methotrexate, azathioprin and cycloposphamide and revascularization procedures such as surgical revascularization and/or percutaneous intervention [6-10]. During the active phase of the disease, the activity can be measured by the symptoms, an increase in the erythrocyte sedimentation rate, $\mathrm{C}$ reactive protein, interleukin-6, computerized tomography, magnetic resonance imaging, and fluorodeoxyglucose positron emission imaging [11-13], corticosteroids have been shown to improve systemic inflammatory symptoms within a few days or week. Immunosuppressive drugs such as methotrexate, azathioprin or cyclophosphamide have been used when steroids could not induce remission. In the chronic stage of this disease, the aim of treatment is revascularization of the affected organ, either by surgery or percutaneous intervention [8-10, 14]. Surgical treatment has been used to bypass the stenosed segment. This procedure may be complex and difficult, because it requires an intrathoracic approach, and is often complicated by graft occlusion and anastomotic site aneurysm. The stenotic lesions such as subclavian, carotid, brachial and renal in TA have been successfully treated with percutaneous intervention that has proved safe and with a good cost-benefit ratio, thus being an alternative for surgical revascularization [9, 10, 14]. Stent may achieve larger arterial lumen diameters, and may also eradicate or remarkably decrease gradients across stenotic lesions. Although recurrence of stenosis in patient with TA has been observed in $44.4 \%$ during angioplasty, $17.6 \%$ has been observed during angioplasty with stenting [15]. Also, the stents may not yield long-term arterial lumen patency in patients with TA as compared to atherosclerotic lesions [16]. However, recurrence of stenosis in patient with TA has been treated successfully by reintervention without significant complications, as in our woman patient [15]. Compared to atherosclerotic lesions, the lesions in patients with TA are very rigid due to their extensively diffuse, fibrotic, eccentric and calcified nature $[17,18]$. To successful stenting in patients with TA, the rigid vessels can be dilated carefully with adequately high pressure. Since higher balloon inflation pressure causes chest pain, intimae dissection, bradycardia, and hypotension, close monitoring is required during procedure [19].

In this study, we were successfully performed percutaneous intervention in the subclavian, brachial, renal, carotid and coronary arteries. Narrowing of the brachiocephalic arteries is a common manifestation of peripheral vascular disease such as TA [20]. Of all the brachiocephalic artery origins, the left subclavian artery is usually the most severely affected. Percutaneous intervention such as angioplasty and/or stenting is still the most common method for percutaneous revascularization of subclavian and bra- 
chial artery stenosis, especially short lesions. Fritz Angle et al [20] showed that percutaneous angioplasty/stenting of subclavian artery stenosis can be done with a very high technical success rate, as in our study. In this study, two patients treated before coronary artery bypass surgery and had a LIMA bypass graft. One of these patients had significant stenosis of the proximal left subclavian artery and right coronary artery and treated with stent. Use of the LIMA is associated with the best long-term patency of coronary artery bypass surgeries. However, significant stenosis of the proximal left subclavian artery can compromise flow to the LIMA. In patients with LIMA-coronary artery bypass, the development of left subclavian artery stenosis may cause angina, as in our patient, or myocardial infarction. Treatment options include percutaneous interventions or surgical revascularization. Surgery involves a carotid-to-distal subclavian bypass graft, or a subclavian-carotid transposition. The morbidity and mortality rates related to these surgical options are raised markedly by the presence of severe coronary artery disease. For this reason, we used percutaneous intervention in this patient.

Carotid artery stenting is a good technique that represents a therapeutic alternative to carotid endarterectomy for patients with significant carotid stenosis, as in our patient. Procedures in the carotid arteries were performed with a distal embolic protection device, as in our patient, with the purpose of reducing the risk of stroke during stent implantation. Compared to endarterectomy stenting is much less invasive and traumatic procedure. Also, it is

\section{References}

1. Brunner J, Feldman BM, Tyrrell PN, et al. Takayasu arteritis in children and adolescents. Rheumatology (Oxford). 2010;49: 1806-14.

2. Ishikawa K, Maetani S. Long-term outcome for 120 Japanese patients with Takayasu's disease. Clinical and statistical analysis of related prognostic factors. Circulation 1994;90: 1855-60.

3. Kim HJ, Lee CS, Kim JS, et al. Outcomes after endovascular treatment of symptomatic patients with Takayasu's arteritis. Interv Neuroradiol 2011;17: 252-60.

4. Alvarez-Hernández E. Treatment of large vessel vasculitis. Reumatol Clin 2011;7 Suppl 3: S28-32.

5. Bloch DA, Michel BA, Hunder GG, et al. The American College of Rheumatology 1990 criteria for the classification of vasculitis. Patients and methods. Arthritis Rheum 1990;33: 1068-73.

6. Shelhamer JH, Volkman DJ, Parrillo JE, et al. Takayasu's arteritis and its therapy. Ann Intern Med 1985;103: 121-6.

7. Hoffmann GS, Leavitt RY, Kerr GS, et al. Treatment of glucocorticoid-resistant or relapsing Takayasu arteritis with methotrexate. Arthritis Rheum 1994;37: 578-82.

8. Giordano JM. Surgical treatment of Takayasu's arteritis. Int J Cardiol 2000;75 (Suppl 1): S123-8.

9. Sharma BK, Jain S, Bali HK, et al. A follow-up study of balloon angioplasty and de-novo stenting in Takayasu arteritis. Int J Cardiol 2000;75 (Suppl 1): S147-52.

10. Gradden C, McWilliams R, Gould D, et al. Multiple stenting in Takayasu arteritis. J Endovasc Ther 2002;9: 936-40.

11. Hoffman GS, Ahmed AE. Surrogate markers of disease activity in patients with Takayasu arteritis. A preliminary report from The International Network for the Study of the Systemic Vasculitides (INSSYS) Int J Cardiol 1998;66 (Suppl 1): S191-4.

12. Andrew J, Al-Nahhas A, Pennell DJ, et al. Non-invasive imaging in the diagnosis and management of Takayasu's arteritis. Ann Rheum Dis 2004;63:995-1000.

13. Choe YH, Han BK, Koh EM, Kim DK, Do YS, Lee WR. Takayasu's arteritis: assessment of disease activity with contrastenhanced MR imaging. Am J Roentgenol 2000;175:505-511. technically simpler and faster than surgical endarterectomy. Finally, this procedure can be done with remarkably complications rates [21, 22].

Renal artery stenosis is the most common cause of secondary hypertension. Many of the stenosis progress to total occlusion and with the majority of the patients suffering loss of renal function manifested by increasing serum blood urea nitrogen and creatinine. Treatment of renal artery stenosis via percutaneous intervention may improve amelioration of blood pressure and/or renal functions [23, 24]. In this study, we observed both a better control of the blood pressure and preservation of the renal function.

\section{Conclusion}

In conclusion, Takayasu's patients with active systemic disease must receive immunosuppressive therapy such as corticosteroids, methotrexate, azathioprin and cycloposphamide before percutaneous intervention. Percutaneous interventions were performed after the active period such as during normal erythrocyte sedimentation rate. In these circumstances, percutaneous intervention in patient with TA may be safely and much less traumatic. Also, recurrence of stenosis in patient with TA have been treated successfully by reintervention without significant complications,

\section{Study Limitations}

These conclusions may not extend to the great population, therefore; the results of this study will need confirmation in larger studies.

14. Bali HK, Jain S, Jain A, et al. Stent supported angioplasty in Takayasu arteritis. Int $\mathrm{J}$ Cardiol 1998;66 (Suppl 1): S213-7.

15. Lee BB, Laredo J, Neville R, et al. Endovascular management of takayasu arteritis: is it a durable option? Vascular 2009;17: 138-46.

16. Liang P, Hoffman GS. Advances in the medical and surgical treatment of Takayasu arteritis. Curr Opin Rheumatol 2005;17: 16-24.

17. Ozdil E, Parikh DK, Krajcer Z, Angelini P. Stent placement in a patient with Takayasu's arteritis. Cathet Cardiovasc Diagn 1996;38: 373-6.

18. Tyagi S, Kaul UA, Nair M, Sethi KK, Arora R, Khalilullah M. Balloon angioplasty of the aorta in Takayasu's arteritis: initial and long-term results. Am Heart J 1992;124: 876-82.

19. Miyamoto S, Wu H, Kubo T, et al. Single stage multiple stenting in Takayasu's arteritis. Case report. Neurol Med Chir (Tokyo) 2012;52: 219-23.

20. Fritz Angle $\mathrm{J}$, Matsumoto $\mathrm{AH}$, Kevin McGraw J, et al. Percutaneous angioplasty and stenting of left subclavian artery stenosis in patients with left internal mammary-coronary bypass grafts: Clinical experience and long-term follow-up. Vascular and endovascular surgery 2003;37: 89-97.

21. Yadav JS, Wholey MH, Kuntz RE, et al. Stenting and Angioplasty with Protection in Patients at High Risk for Endarterectomy Investigators. Protected carotid-artery stenting versus endarterectomy in high-risk patients. N Engl J Med 2004;351: 1493-501.

22. Wholey M, Eles G. Clinical experience in cervical carotid artery stent placement. Carotid Neurovasc Int 1998;50: 301-6.

23. Textor SC, Wilcox CS. Renal artery stenosis: A Common, treatable cause of renal failure? Annu Rev Med 2001;52: 421-42.

24. Webster J, Marshall F, Abdalla M, et al. Randomised comparison of percutaneous angioplasty vs continued medical therapy for hypertensive patients with atheromatous renal artery stenosis. Scottish and Newcastle Renal Artery Stenosis Collaborative Group. J Hum Hypertens 1998;12: 329-35. 